\title{
HISTÓRIA, LITERATURA E MEMÓRIA DO ESPAÇO URBANO NA FICÇÃO DE MOACYR SCLIAR
}

Charles Monteiro*

Abstract - The author provides an analysis about how Moacyr Scliar through his fiction novels rethinks the memory and the urban identity of the Porto-alegrense society.

"O homem nảo pode falar seu pensamento sem pensar sua palavra" (Bonald).

"Somos construídos como memória, somos a um só tempo a infância, a adolescência, a velhice e a maturidade" (Felini).

A tarefa a que me proponho é realizar um ensaio teórico experimental acerca dos movimentos da memória sobre o espaço urbano de Porto Alegre na Literatura de ficção de Moacyr Scliar. Me arrisco a tratar de um tema tão antigo e atual, por isso tão complexo como História e Literatura, porque acredito que ele esteja no centro das preocupaçốes atuais na re-discussão dos limites do campo do saber histórico. Porque instiga a pensar sobre as possibilidades e limites da

* Professor no Departamento de História da Pontifícia Universidade Católica do Rio Grande do Sul, Porto Alegre, Brasil. 
interpretação histórica no momento em que se observa a dissolução das antigas fronteiras e certezas, persistentemente construídas no século XIX, que separavam as disciplinas acadêmicas. Somente através da leitura e do diálogo, sobre os textos de Moacyr Scliar, com o leitor especializado poderei acercar-me da compreensão desta problemática. Percurso que o meu pensamento só poderá percorrer circundando os dois campos, andando ao redor em círculos concêntricos, flertando com esta área sombreada onde História e Literatura se tocam e entrelaçam suas malhas. Onde torna-se possível perceber as suas teceduras, as dobras e redobras da narrativa que envolvem e interiorizam o espaço urbano (Deleuze, 1991).

Escrevo para dialogar com aqueles que pensam ser a História mais que um método de conhecimento, uma postura crítica diante da vida, como diria Sérgio Buarque de Holanda. Penso como aqueles que fundam suas práticas num princípio crítico e no diálogo com outras disciplinas, e não apenas em regras e proibições de uma campo disciplinar.

A História, enquanto campo de produção de saber, esteve ligada desde seu "momento fundador" com Heródoto à Literatura pela literalidade, ou seja, à poeticidade da linguagem e à experimentação na forma de expressão escrita. Esta literalidade está presente na forma de Heródoto narrar a história, mesclando relatos orais, mitos e o conhecimento de textos com descrições etnográficas e etnologia. Porém, o processo de constituição da história como ciência iria estabelecer e marcar as diferenças entre esses dois campos de representação da cultura. Distinção que repousa sobre a identificação da Literatura ao ficcional, ao irreal, e a História ao real, àquilo que aconteceu, à verdade. A invenção da noção de conhecimento histórico como um duplo verdadeiro do passado (mimesis) está fundada na crença do acontecimento unívoco e na fé na realidade do registro escrito como testemunha e prova jurídica dos acontecimentos.

O método histórico, a crítica documental desenvolvida ao longo do século XIX, viria a estabelecer a História no campo das ciências e afastá-la da Literatura, considerada pertencente à esfera da arte. A divisão social do trabalho intelectual começava a se fazer no bojo da construção da sociedade e da cultura burguesa. Muito embora, ao longo deste mesmo séc. XIX, os projetos literários de Balzac ou Zola fossem conscientemente o de realizar a crítica das práticas sociais e 
políticas da sociedade francesa. Disso não resta dúvida para quem lê, por exemplo, Pai Goriot de Balzac ou Germinal de Zola. Uma parte das importantes obras literárias da época aparecia primeiro em forma de folhetim no jornal, atingindo um grande público, para posteriormente serem publicadas em livro. A literatura constituía-se numa espécie de contrapoder da sociedade em relação à consolidação do Estado, da burocracia, da moral burguesa e da nova microfísica de poderes.

Nos dias de hoje, críticos literários e historiadores têm contestado essa oposição simplista. Nem a História poderia ser considerada simplesmente como portadora da verdade dos conhecimentos do passado, devido às múltiplas mediações e revisões da historiografia, que expõe o seu caráter construído do saber produzido pelo historiador. Nem a Literatura seria simplesmente ficção, irrealidade completa, divorciada da verdade (Barthes, 1988; Frye, 1973; Ricoeur, 1994; Riedel, 1988; White, 1992, 1994). Tanto a História quanto a Literatura são construídas a partir de um lugar social de onde se narra (classe, etnia, sexo, instituição, métier) e se tematiza a realidade, porém a forma e os compromissos que permeiam esse "dizer" do real é que são próprios a cada uma delas. A partir de Foucault, é mais importante compreender "como" as narrativas e os discursos funcionam do que propriamente "o que" dizem.

$\mathrm{Na}$ tradição portuguesa encontramos essa mescla da Literatura à História nos Lusíadas. Camões canta/narra a epopéia da conquista dos novos mundos pelos portugueses, mas também produz o texto fundador da moderna língua portuguesa. A historiografia brasileira percorreria um longo caminho das crônicas da conquista, dos sermôes e poemas religiosos (elogios literários da colonização de um Rocha Pita, visando um lugar na Academia Portuguesa de Letras), até a constituição de acervos documentais e a criação de Institutos Históricos e Geográficos no Império. A partir daí, um dos objetivos da produção historiográfica e literária seria o de pensar a formação da sociedade e da cultura brasileira (Nação), muitas vezes legitimando o projeto de um Estado nacional centralizado e seu aparato de representação burocrático e cultural.

Na década de 1930, as reinterpretações da história e da cultura brasileira realizadas por Sérgio Buarque de Holanda, em Raízes do Brasil, e por Gilberto Freyre, em Casa grande \& senzala, teriam tam- 
bém suas marcas literárias no tom ensaístico, na forma e no ritmo da narrativa. Como de resto foram lidas e apreciadas por um público bastante mais amplo que o especializado. O que está diretamente ligado ao tipo de formação da elite intelectual brasileira anterior à constituição dos cursos universitários de História, muitos eram egressos dos cursos de Direito, Medicina e Engenharia. Detinham um saber plural e erudito, ao mesmo tempo que arqueologizavam arquivos e discutiam as teorias "científicas" européias, eram ávidos leitores de romances e poesias (dos simbolistas e parnasianos a Proust e os modernistas). O discurso histórico de ambos sobre a cultura e a sociedade brasileira (suas origens e desenvolvimento) seria repetidamente retomado como paradigma para interpretar a dinâmica e as tarefas históricas do Estado nacional que emerge do movimento de 1930.

Atualmente, os historiadores têm trabalhado sobre a Literatura a partir de diferentes enfoques, objetivos e problemáticas de pesquisa. Não tomarei aqui a Literatura como fonte para o estudo da formação urbana ou para narrar a história da modernizaçăo urbana de Porto Alegre, como fiz em outro momento (Monteiro, 1995). Também nāo pretendo a partir dessas obras reconstruir um contexto histórico cujas pistas estariam no interior do texto narrativo. Mas, tomarei as novelas de Moacyr Scliar como falas da cidade, ecos do imaginário urbano que emergem do texto, como uma re-leitura/atualização da memória coletiva (Sansot, 1988). A partir da análise interna das obras busco compreender a constituição do texto, a re-elaboaração do imaginário urbano, dos mitos de fundação da cidade e da história de um corpo coletivo que se enriquece com novos conteúdos culturais. Tentarei compreender a relação entre memória e História, Literatura e imaginário urbano (enquanto regimes de imagens). Pretendo deslocar-me do campo da observação para o campo da interpretação, da linguagem, do discursivo, da palavra.

O escritor-autor é antes cidadão-leitor, que em sua narrativa sobre o espaço urbano tece a intriga do texto lançando mão de suas experiências de vida e da sua "biblioteca imaginária". Isto é, escreve a partir de um universo de referências culturais que têm origem na sua experiência de habitante da cidade, na recepção de tradições orais, na re-elaboração individual do patrimônio da memória coletiva, em aprendizagens formais escolares da História, na leitura de textos variados como crônicas, romances e artigos jornalísticos, além de textos teóricos, filosóficos e religiosos da cultura universal. O texto de fic- 
ção urbana de Scliar trama, seleciona, costura, dando cor e densidade a um conjunto muito variado de referências e citações culturais da ordem do local e do universal, através de múltiplas mediaçōes do regional e do nacional, expressando uma circulação de significados na representação do urbano. O escritor, como também o historiador, é intermediário cultural entre diferentes espaços de prática social e representação da cultura urbana. "Lugares" de onde fala e que se sobrepõem, se sedimentam e se opõem na sua escritura. Uma harmonia conflitual se expressa no texto pelas ênfases, silêncios, esquecimentos e normalizações sobre as experiências de um corpo social.

Scliar realiza em sua obra de ficção uma releitura da tradição oral, da memória coletiva, das crônicas e a história escrita sobre Porto Alegre. Ele recria na sua escritura uma forma de repetição diferenciada de elementos da memória e seus conteúdos de experiência sóciocultural. Essa releitura promove uma atualização, uma re-acomodação dos cristais da memória que se encontram em diferentes lençóis do tempo, numa nova dobra onde vão se encontrar as pontas do presente do futuro, do presente do presente e do presente do passado (Deleuze, 1985). A sua compreensão, então, se dá por meio do deslocamento entre os cristais da memória situados nos lençóis do passado e as pontas do presente reunidas na escritura (Deleuze, 1991). Pretendo realizar um diálogo com essas narrativas ficcionais, a partir de uma leitura historicizada no presente que contém essas "outras" temporalidades. O meu objetivo é agregar algo à compreensão deste saber sobre a memória da formação do espaço urbano de Porto Alegre. De acordo com o ditado popular: "quem conta um conto, aumenta um ponto".

Para perceber esses movimentos entre memória, História e Literatura sobre o espaço urbano de Porto Alegre selecionei arbitrariamente três novelas de ficção de Moacyr Scliar: A Guerra do Bom Fim (1972), Os deuses de Raquel (1978) e Os voluntários (1979). Em primeiro lugar, o motivo desta escolha era o fato de serem três novelas de ficção de Scliar que tematizam de maneira explícita espaços urbanos da cidade de Porto Alegre. Em segundo lugar, todas as três foram escritas e publicadas na década de 1970. Década que, por um lado, caracteriza-se como momento particular para a intelectualidade brasileira, quando as palavras assumem um importância dramática diante da ordem ditatorial. Não é por acaso a escolha de Scliar da narrativa de ficção, do fantástico como forma crítica de superação do discurso hegemônico. Por outro lado, evidencia uma nova forma de 
pensar o espaço urbano através da elaboração dos planos diretores e da realização de grandes obras públicas. Plano diretor que permite a modernização acelerada do espaço urbano, destruindo certos marcos da memória coletiva. Daí a necessidade de reconstruí-los em outro espaço ou "lugar da memória", na Literatura, na História, no imaginário.

Em princípio, a intenção era de comparar o processo de ficcionalização do Bairro do Bom Fim (de imigração judaica, próximo ao centro), ao Bairro do Partenon (mais afastado com seus casarões, colégio e Hospício São Pedro - que por ironia leva o antigo nome da Província), à rua Voluntários da Pátria no centro da cidade. Contudo, na medida das re-leituras destas três obras de Scliar ficou claro para mim a predominância da problemática da memória, da pluralidade dos tempos narrativos e da identidade numa cultura de "mescla" (Sarlo, 1988). A questão de uma identidade de "mescla" ou "mestiça" inscreve-se nos quadros de uma cultura regional marcada por conflitos militares pela demarcação das fronteiras com os países de colonização espanhola (Argentina e Uruguai), momentos de confronto com o poder central (Guerra dos Farrapos, Revolução de 1893) e de forte imigração européia. São temas importantes postos pela tradição literária gaúcha que se encontram no subsolo da narrativa ficcional de Scliar, e para os quais ele formula as suas respostas.

Segundo Chaves (1994, p. 73), a literatura rio-grandense se caracterizou por uma temática regionalista e histórica que privilegiava a figura do gaúcho, seus hábitos e costumes. Porém, a partir de 1935, Érico Veríssimo no chamado "Ciclo de Porto Alegre" e Dionélio Machado em Os Ratos inauguram a ficção urbana no Rio Grande do Sul. Moacyr Scliar é herdeiro desta tradição, renovando-a ao introduzir a questão da imigração judaica no contexto da formação da identidade local, regional e brasileira, principalmente ao problematizar a inserção desse grupo étnico nas camadas médias urbanas. Inovação também formal no tocante a uma ficção urbana construída como fantástica, onde os tempos, os espaços e o "eu" e o "ele" da narrativa se misturam e se confundem. Seus personagens centrais são os "gauches" da vida, que na tentativa de compreender a fatalidade do seu destino, realizam um mergulho na sua história de vida e na do grupo (familiar, étnico, geracional). 
Alguns críticos literários chamaram atenção sobre a questão central do judaísmo na obra de Moacyr Scliar (Simone, 1976; Marobin, 1985), outros para a questão do fantástico (Zilberman, 1986; Pötter, 1984), e outros ainda para a relação entre vida e o processo de produção literário (Steen, 1981). Uma única dissertação de mestrado, no Instituto de Letras e Artes da PUCRS, tematiza a relação entre História e Ficcção na obra de Scliar através de A Estranha Nação de Rafael Mendes (Selistre, 1991). O interessante deste trabalho é a busca de fazer um paralelo entre a narrativa ficcional de Scliar, que aborda a trajetória de uma família judia (desde a sua chegada ao Brasil, ao Rio Grande do Sul, ao campo, o êxodo para Porto Alegre e a sua ascensão social), com a tentativa de escrever uma "outra" História do Rio Grande do Sul. Nesse sentido, a Literatura de ficção preencheria uma lacuna deixada pela historiografia, problematizando e abordando de forma crítica a questão da identidade regional. Tarefa que lhe coubera nas décadas de 1930 e 1940 com a invenção da figura do gaúcho como o "monarca das coxilhas".

No entanto, se a temática do judaísmo e da identidade é evidente, se a questão da forma da escrita como instauradora de um universo fantástico já não o é tanto; a questão de fundo sobre as diferentes temporalidades imbricadas com os movimentos da memória (individual, coletiva, escrita, oral) como constituidora das identidade nunca foi problematizada como eixo central do processo narrativo na obra de Scliar. É justamente a discussão dessa contribuição que julgo mais importante na busca de repensar as aproximações possíveis entre História e Literatura. Perspectiva extremamente frutífera para pensar a questão da temporalidade nas narrativas históricas, do discurso historiográfico, e a relação problemática entre memória e História.

A questão é compreender os marcos da experiência coletiva e os diversos tempos que articulam os "lugares da memória" e a percepção de uma identidade em tensão através da narrativa literária. Narrativa que costura e reúne as pontas do presente ao construir "pontes" entre esses "lugares da memória" e a enunciação dos "sujeitos". Na forma como o narrador conta a sua história e, a partir dela, recria sua identidade e a do grupo étnico. Um esforço de compreensão que deve ser conduzido através de um trabalho de glosador à margem do texto, percebendo as intertextualidades e propondo um novo olhar e uma nova "síntese" sobre a história da sociedade porto-alegrense. 
Em primeiro lugar, é necessário compreender a condição deste escritor dentro de uma cultura "mestiça", em que os referenciais da cultura européia, as muitas migraçôes e os nomadismos no território urbano exigem uma contínua reorganização dos grupos, dos consensos, dos laços identitários. Laços que estabelecem uma tensão como as construçōes das identidades regional e nacional. Os conteúdos expressos pela memória são re-leituras tanto de elementos do imaginário da cultura latina, judaico-cristã, quanto de elementos herdados das gerações ascendentes e de narrativas de cultura. Mas, sobretudo, uma atualização da memória coletiva relacionada às demandas do presente, da contemporaneidade que se impõe como princípio ordenador e produtor da memória e da identidade. Esta própria uma síntese tensional e sempre provisória dessas várias temporalidades e experiências socioculturais.

Há relações explícitas na tecedura dessas três novelas com uma re-leitura das crônicas sobre Porto Alegre (ver Scliar, 1978, p. 10), com elementos autobiográficos (Steen, 1981, p. 173-174) ligados a experiências de vida mediadas pela memória ["As famílias se reuniam em torno da mesa da cozinha. Um samovar fumegava. [...] Contava-se uma história da Rússia, outra história da Rússia.” (1972, p. 10)] e uma re-leitura da Literatura Rio-grandense (Érico Veríssimo) mesclada à nacional e à internacional (a Torá, Jorge Luís Borges e a ficção policial americana). O que fica explicitado tanto na entrevista concedida por Scliar à Edla Steen (1981, p. 178), quanto na reflexão sobre a escritura presente na sua obra: "Penso nos livros que li, nas canções que escutei, nos filmes que vi. Assim é o mundo, com sua trama de delicados fios" (Scliar, 1972, p. 35). Se existe uma intertextualidade evidente no texto de Scliar, existe também uma intratextualidade comprovada pelo reaparecimento constante dos mesmos temas e pelo repensar da trajetória da escritura dentro da sua obra.

Scliar mescla na sua escritura uma narrativa na primeira pessoa, como no caso do narrador-protagonista Paulo em Os voluntários, e na terceira pessoa, como no caso de Os deuses de Raquel, onde a narrador-testemunha é Miguel (profeta, portador da verdade revelada da visão profética que tudo abarca) e um narrador-indeterminado-intruso em A Guerra do Bom Fim. Essa oscilação entre a primeira e a terceira pessoas caracteriza um jogo de aproximação e distanciamento do passado e das personagens que evidencia os "trabalhos da memória". A minha memória e a do outro que diz tanto sobre mim e da minha his- 
tória, me ajudando a definir a minha identidade por oposição, negação ou nuança. Vai-e-vém através dos tempos verbais numa alternância das temporalidades entre o presente do passado e o futuro do passado. Essa polifonia de vozes, essa ambivalência temporal do discurso narrativo promove uma circulação de significados entre passado, presente e futuro na busca de uma identidade e da inteligibilidade do presente. A dialogicidade entre o discurso do narrador-protagonista onisciente, as vozes das outras personagens (da enunciação do discurso) e do enunciado da história provocam uma circularidade entre texto e contexto e entre temporalidades numa expressão crítica e criativa da linguagem sobre o real. Linguagem instauradora de novos significados e interpretações da cultura, portadora da tensão entre a minha fala e as outras falas (a fala do "outro").

Na novela de ficção A Guerra no Bom Fim Scliar pratica uma poética dos tempos, da memória, que expõe uma "cartografia sentimental" dos espaços da cidade. Scliar descreve o bairro do Bom Fim como um território especial ("país") à parte no tecido urbano de Porto Alegre. Lá estão as famílias judias emigradas da Rússia, Polônia, Hungria, Lituânia, Alemanha e Oriente. Alguns tendo passado pelas colônias do interior como Philippson, formada pela Jewish Colonization Association (JCA), ou cidades do interior: Quatro Irmãos e Erechim. Onde muitos não tiveram sucesso, pois não eram originariamente agricultores, e após saldarem suas dívidas partiram para a capital. Outros tinham vindo diretamente para Porto Alegre, às vezes tendo passado pelo Rio de Janeiro, Montevidéu ou Buenos Aires.' A narrativa tem a guerra na Europa como pano de fundo, notícias pelo rádio que fazem lembrar os Pogroms da Rússia. A narrativa está centrada na história de Joel e da sua família. Seu pai é mascate e percorre, primeiro de carroça e depois de camioneta, a cidade vendendo fazendas e miudezas a crédito. As histórias da infância de Joel, de sua educação, brincadeiras e da turma (dos amigos também filhos de judeus) nos traçam um perfil do bairro e das redes socioeconômicas que os imigrantes judeus formam para se estabelecerem na sociedade de Porto Alegre.

1 O que é comprovado por pesquisas históricas, ver Moacyr FLORES. História do Rio Grande do Sul. Porto Alegre: Nova Dimensão, 1988, p. 119-120. 
O regime de imagens fundado sobre a "água” é um dos elementos predominantes da re-criação poética do espaço mediada pela memória (a enchente de 1941, o quintal que se torna um mar, o combate de Capão da Canoa, a imigração através do Atlântico). Um navegar entre uma memória já "estabilizada" dos espaços urbanos com foros realistas no enunciado da história e a memória movediça da enunciação do discurso na narração das experiências de vida dos personagens, em permanente acréscimo e mutação ao longo do texto. Uma tensão contínua entre a idéia do povo-comunidade (baseado numa religiãomemória fundada na Torá e na palavra revelada como forma de atualização da aliança) e as outras identidades em efeito de "negativo": o negro feiticeiro do Morro da Velha, as três mulatas da colônia africana, o alemão nazista do botequim do Morro da Velha, até mesmo os judeus ricos e os levantinos.

Em Os deuses de Raquel, Scliar vai tecendo a história de Raquel, do Bairro Partenon, dos imigrantes judeus e da psiquiatria no Rio Grande do Sul. Bairro que leva este nome por causa da existência neste arrabalde da cidade no séc. XIX do Partenon Literário, responsável por reunir a primeira geração de escritores gaúchos bastante atuantes em causas sociais e na política. Não é por acaso que na narrativa Scliar faz o pai de Raquel, o latinista húngaro Ferenc, residir no Partenon. Existe uma certa ironia por trás do fracasso de Ferenc em criar uma escola de latim e seu posterior estabelecimento como dono de uma loja de ferragens naquele bairro. Arrabalde de passado glorioso, mas que no presente é o "lugar" dos loucos. O que está presente na história do personagem-narrador Miguel, o "profeta" que trabalha na ferragem do pai de Raquel, que de tempos em tempos se auto-interna no Hospício São Pedro. E pela própria história de Raquel que luta contra a loucura para entender a sua identidade, a sua história que parece estar fora de "lugar".

A narrativa vai e volta no tempo, mistura o presente de Raquel e suas memórias da infância, adolescência e idade adulta, sempre acompanhadas de perto por um olho que "tudo vê e tudo sabe", à medida que ela guia seu carro pelas ruas da cidade. Existe, também, uma simultaneidade entre o ritmo das lembranças sobre episódios da vida de Raquel, a modernização da cidade e a construção do templo por Miguel (a construção da História?) e, também, o livro que Miguel escreve (a escrita da História?) que narra a história desses dias: "Os dias de Raquel. Desses deuses: os deuses de Raquel” (1978, p. 80). 
Raquel é representada como uma judia que vive no Partenon, longe do resto da comunidade judaica do Bom Fim. Raquel não estuda no colégio lídiche, mas num colégio de freiras onde, forçada pelo meio e as ameaças de danação eterna, se converte internamente ao cristianismo inventando um culto interior à Virgem. Scliar nos narra uma estratégia de inserção dos imigrantes judeus na sociedade portoalegrense através da educação dos filhos em colégios confessionais. Fato atestado pela própria história de vida do escritor (ver Steen, 1981 , p. 178) e por outros relatos (ver o recente memória escrita por Boris Fausto, 1997, Negócios e ócios). Raquel ama um gói “cocho" de origem alemã (crime contra sua etnia), marido de sua amiga (pecado de adultério), e assume a loja do pai (rompe com o papel sexual da mulher na sociedade gaúcha). Raquel representa os dilemas dos imigrantes judeus em busca de demarcar o "lugar" de sua identidade no espaço urbano: uma territorialidade. Comunidade étnica que luta contra a perda dos seus referenciais culturais em meio à hegemonia cultural e sócio-econômica de grupos anteriores de imigrantes, como o alemão e o italiano. Identidade buscada no contexto de tensão entre nacionalização/integração do Rio Grande do Sul no Estado nacional, e a resistência a esta integração via regionalismo. Regionalismo que vai buscar erigir "lugares da memória" como datas e festas comemorativas (20 de setembro) que reforcem as suas pretensões frente ao governo central.

Em Os voluntários, a história que Paulo conta de sua vida está ligada a de seu pai, como uma espécie de repetição diferenciada. Da mesma maneira que a história de Raquel também estava ligada a história de seu pai. É um tempo herdado, geracional, com toda a sua carga de tensão e contradição. O pai de Paulo, um português que tinha lutado nas colônias na África, chega a Porto Alegre na década de 1930 e se estabelece com um bar-restaurante na rua Voluntários da Pátria: o Lusitânia. O nome da rua é uma homenagem aos "voluntários" que lutaram na Guerra do Paraguai. Porém, se conhece uma charge num jornal da época que mostra um navio onde são embarcados escravos libertos ao lado de imigrantes em ferros para lutar no Paraguai. O que mostra a concepção irônica, complexa e ao mesmo tempo crítica que Scliar tem da História "oficial" ou "tradicional".

Em Os voluntários pode-se ver claramente a existência de dois regimes de imagens (diurno e noturno) na rua Voluntários da Pátria. 
Durante o dia é a rua do comércio miúdo de vestuário, armarinho, vendedores ambulantes, lancherias e escolares. À noite acontece uma inversão. As famílias se recolhem e a Voluntários se enche de luzes, mulheres e das músicas dos cabarés e bares. As sociabilidades noturnas que são a outra face da sociedade conservadora e provinciana de Porto Alegre. Cidade capital e porto comercial que recebe o afluxo de fazendeiros, comerciantes, estudantes vindos do interior e marinheiros de passagem. A prostituição que é tema recorrente na literatura gaúcha desde Erico Verissimo em Noite de 1954 e seria foco de outra novela de Scliar $O$ ciclo das águas (1976).

A noite é o espaço das inversões, onde a prostituta Elvira torna-se a Rainha no cabaré Maipu. Das transgressões, Paulo e Benjamin fogem de casa para se encontrarem com os amigos no Maipu. Mas, também, são os espaços noturnos que permitem o tempo se deter e daremse as inteligibilidades das histórias das personagens. No Maipu, Paulo conhece as histórias de Elvira, do Capitão, de Orígenes, do Reverendo Johnatan. É à noite em sonho que Raquel encontra a Virgem e pede perdão pelos seus pecados, que ela sonha com o pássaro da eternidade. É à noite que ocorrem os combates de Joel e sua turma contra os temíveis alemães que pretendem invadir o Bom Fim. É à noite que os medos se encontram.

Embora em Os voluntários possam se ler as datas que vão balizando o tempo da narrativa, estabelecendo uma certa linearidade, na evolução da história rumo o seu desfecho, este coincide com o ponto de partida da narrativa, que por sua vez é deixada em aberto para o devir nas palavras finais da novela: "Amanhã é outro dia. São outras histórias. Outras viagens, para outros voluntários”. É uma história sem fim, sempre relembrada, atualizada, inacabada e que se projeta para um devir que é pura possibilidade de vir a ser, sem determinação, sem obedecer a um sentido pré-determinado.

Um dos trabalhos do escritor, do produtor de narrativas, é de agir como mediador entre um tempo absoluto/cósmico sobre o qual o homem não tem nenhum controle (a eternidade), o tempo da experiência vivida/quotidiana e o tempo da memória onde diferentes tempos já estão imbricados. O tempo da escritura é ainda um outro tempo, posterior, que se completa com o tempo da leitura. A escritura é a ação de tecer os tempos cósmico, da experiência, da memória, do pensamento no presente. Presente que reúne as diferentes pontas do tempo presente do passado, presente do presente e futuro do presente, projetan- 
do um devir, como potencialidade do ser, possibilidade do vir a ser, que configura um futuro do passado. Tempo no qual o historiador está tão habituado a se mover, já que arqueologiza os vestígios, os sinais do passado no textos visando uma compreensão do presente que leva no seu bojo possibilidades de devir.

O pássaro da eternidade é um bom exemplo desta busca de compreender e mediar os tempos da experiência de vida e da memória. Uma metáfora da invenção do tempo da escritura entre o tempo da experiência, o tempo da memória e o tempo cósmico (à dimensão dos corpos celestes: planetas, estrelas, luas), divino e mítico sobre o qual a vida parece um fragmento ínfimo, desprovido de sentido e incapaz de quebrar a cadeia do surgimento e desaparecimento das geraçōes, culturas e espécies. Raquel pensa, deitada no seu leito, na escuridão da noite que se assemelha à noite de todos os tempos:

"E o pássaro? O pássaro que roça com a ponta da asa a coluna da eternidade?

Pouco se sabe deste pássaro. Apenas é pequeno e cinza, que tem olhinhos pretos, duros e penetrantes; que voa rápido e silencioso. Que não canta. Não emite qualquer som.

De onde vem, a cada mil anos esse pássaro? [...] Sabe-se que volta milênio após milênio, para cumprir a sua tarefa. Quem lhe deu ordens para que o faça? Quem o treinou? Quem deu a ponta de sua asa poder abrasivo para raspar a coluna?

Tudo indica que está resolvido a acabar com a coluna da eternidade, o pequeno pássaro. Mas uma observação mais atenta revela, nele mesmo, os sinais inequívocos da passagem do tempo. $[\ldots]$.

Quando regressar, o Colégio estará em ruínas; o latim será uma língua definitivamente morta; os ossos dos pais descansarão num túmulo qualquer; e Raquel estará no inferno" (Scliar, 1995, p. 20).

Raquel pensa no tempo da eternidade, porque pensa na possibilidade de sua condenação eterna ao inferno, por não ser católica, não confessar seus pecados, não comungar, como seus colegas do espaço opressor e atemorizante do colégio de freiras. Paulo pensa na passagem do tempo, por causa da morte de seu grande amigo de infância Benjamin, ao olhar a superfície granulada do asfalto ou o asfalto esburacado que deixa ver os paralelepípedos. Os trabalhos da sua memória são uma busca de inteligibilidade da sua experiência de vida. 
"O ano era de 1969 , mas não lembro em que ano foi asfaltada a Voluntários, nem que ano tiraram os bondes, nem o ano em que o Maipu fechou, nem o ano da morte de Costa e Silva."

Scliar através da personagem-narrador Paulo de Os voluntários utiliza uma metáfora para exprimir a condição do escritor e historiador que devora, se alimenta, se nutre de histórias. ${ }^{2}$ Paulo inicia a narração pela sentença: "Mas gosto mesmo é de contar histórias. E de comer pastéis” (1979, p. 14). E termina sua história novamente retornando aos pastéis, que são a sua porta ao passado, seu "meio da memória". Paulo evidencia isso na sua fala:

"O senhor me vendo comer, the adivinho a pergunta: por que é que você abre o pastel, antes de comê-lo?

Não sei lhe responder. Mania talvez. Talvez tenha a esperança de um dia encontrar, dentro de um pastel, mesmo murcho e frio, um belo relógio de prata, com o emblema da Liga Hanseática. Claro não há relógio algum, só picadinho de carne e ovo duro.

Mas meu amigo, pense neste pastel. Pense na massa de que é feito. Pense na farinha. Pense no trigo, que cresceu dourado ao sol do Rio Grande do Sul, para dar os grãos que, triturados resultam nessa farinha.

Pense na carne. Pense no boi, que ao crepúsculo morria. [...]

Pense no ovo. [...]" (Scliar, 1979, p. 203).

O pastel que Paulo come em forma de protesto, segundo suas próprias palavras, é o tempo reencontrado metaforizado no relógio. A memória de um passado "glorioso" povoado por cavaleiros andantes, Sisenando (o cruzado mudo), do pai oficial do exército colonial português, pela epopéia das navegações, travessias e conquistas no Atlântico, pelos grandes amigos já mortos e pelas muitas aventuras. A memória que redime o presente, onde a sua barriga cresce afastando-o do balcão, quando passa o tempo a contar histórias e a devorar pastéis. O prazer oral de contar histórias e devorar pastéis. A oralidade que liga os dois atos possibilita a construção de sua identidade, supe-

2 Nesse sentido é interessante a comparação de Paulo com Jules Michelet analisado na obra Michelet de Roland Barthes. Não sei se Scliar tinha conhecimento deste texto quando escreveu Os voluntários (1979), já que a primeira edição deste livro é de 1954, sua reedição em francês de 1988, e sua edição em português, no Brasil, pela Companhia das Letras, apenas de 1988. Mas a metáfora é muito próxima, talvez possamos atribuí-la com mais segurança a uma comparação premeditada com a madeleine de Proust. 
rar o tempo presente ao atualizar o passado, perpetuar a vida para além da morte e das mutações do espaço urbano. Essa memória, potência de vida, que ele lega aos filhos ao contar-lhes histórias e ao dar-lhes um barco de presente - um esquife chamado "Voluntários" com o qual remam aos fins-de-semana no Guaíba. No entanto, essa memória não é nada "voluntária" ou ocasional, pode sê-lo no momento de partida ao transportá-lo para o passado, fazê-lo experienciar uma "outra" temporalidade. A narração de sua história é um trabalho sobre a memória, uma construção onde interfere uma causalidade intelectual, muito embora ela não seja imperativa e permita as vacilações, as dúvidas, os hiatos e conjecturas da narrativa na enunciação.

Os espaços tornam-se então uma outra dimensão dessa reflexão, ampliando a poética dos tempos tramada na enunciação por uma poética dos espaços. Scliar não realiza uma descrição objetiva dos espaços urbanos de Porto Alegre, ele o faz através da fala dos seus personagens à medida que eles relembram e contam as suas vidas. É uma cidade que está sob a pele das personagens, diretamente ligada às suas experiências de vida, realizações e muitas perdas. A cidade é um teatro de individualidades, ou de quase-sujeitos, pois estes estão sempre à procura de si mesmos, de entenderem suas "histórias". Já estas duas dessas três narrativas são narradas em retrospecto: Os deuses de $R a$ quel e Os voluntários. Em Proust, a taça de chá e a madeleine fazem aparecer os caminhos e prédios de Combray. Em Scliar, a fala da personagem-narrador Paulo, em Os voluntários, transforma o Bar Lusitânia no espaço síntese que condensa os outros espaços e tempos da memória: a Voluntários, o cabaré Maipu, Jerusalém, o Guaíba e tantos outros. A rua Voluntários da Pátria se transforma no rebocador "Voluntários" que se desprende do continente para navegar rumo a Jerusalém, à Terra Prometida, onde as utopias se realizarão e o passado será redimido, porque o tempo será superado e a identidade com o Ser alcançada.

Nesse sentido a outra cidade, a cidade sagrada de Jerusalém (a Cidade de Deus) fala da cidade de Porto Alegre e seus lugares da memória (a cidade do homem). Cidade de Porto Alegre que também figura como uma encruzilhada das diferentes migrações e buscas da terra prometida. Onde o "homo brasilis", como herdeiro da epopéia dos cruzados, dos portugueses, espanhóis, italianos, alemães, ameríndios, negros, judeus e palestinos, vai tentar reconstruir sua vida e his- 
tória, recriando o passado para superar os ultrajes do tempo, os traumas do passado e estabilizar as identidades no presente.

Identidade que é um eterno fazer-se nesta cultura mestiça, nem européia, nem ameríndia, nem africana. Mas a mescla destas numa outra que é diferente e que mantém com elas uma tensão, uma harmonia conflitual interna. É desse espaço e sobre este lugar da construção da memória, que escreve o escritor latino-americano. É desse dilema que ele deve dar conta na sua escritura, na sua forma de narrar a história. Uma forma que necessariamente apela para a mescla dos gêneros clássicos da epopéia (dos conquistadores), do drama (dos imigrantes, da terra e da natureza), da tragédia (dos ameríndios e negros), da comédia (dos hábitos transplantados) e da ironia (dos transformismos políticos e sociais e do eterno retorno do mesmo sob a face do outro, da mudança).

O lugar do qual os narradores-protagonistas narram é o da memória individual que se apropria da memória dos outros (coletiva). Os espaços de ação são geralmente os da esfera privada (a casa, o bar, a loja, o templo) que mantém uma tensão com a rua (Voluntários, Fernandes Vieira, Osvaldo Aranha, Henrique Dias) que é o espaço do conflito, disputado com o outro (os negros da Colônia Africana, os alemães, os palestinos). É na rua que os conflitos ocorrem e teatralizam os conflitos do outro lado do Atlântico (a II Guerra Mundial, a Guerra dos Seis Dias), ou deste lado como o Golpe Militar e a Emenda Constitucional que contrastam com uma certa normalidade e os dramas pessoais das personagens no quotidiano do Bom Fim, da Voluntários, do Partenon.

A cidade narrada por Scliar, através de seus narradoresprotagonistas e narradores oniscientes intrusos (Leite, 1997), é uma cidade de imigrantes e de filhos de imigrantes que, à medida que buscam reconstruir suas vidas numa Porto Alegre também cambiante, se defrontam com a necessidade de recriarem desde o presente um passado. Estabelecer pontos de referência para a sua identidade. Cidade de Porto Alegre que se moderniza e se torna outra, embora conservando sempre algo de seu passado de vila, de porto comercial. Nela, eles reelaboram o passado apelando à memória, fundada tanto em experiências vividas quanto na experiência e na memória dos outros, apropriada por eles no sentido de marcar a sua identidade, seus elos e compromissos com o passado, que é também presente e permite "so- 
nhar" um futuro nesta "terra nova". A cidade é narrada pelos "tipos" humanos que a compóem como um mosaico, uma colcha de múltiplas nacionalidades que mesclam a suas falas à fala local. Narra a história da inserção de um grupo étnico na sociedade e no tecido urbano de Porto Alegre à medida que narra as várias pequenas histórias (biografias), as "pequenas" vidas entrelaçadas na história "maior" da formação da sociedade e da cultura rio-grandense. Esses imigrantes assumem conflitualmente em parte um passado social e cultural (local e regional) que não é propriamente seu, mas diz da vontade de pertencer e ser reconhecido como parte deste corpo coletivo, desta "comunidade imaginária" e da invenção do quotidiano no espaço urbano de Porto Alegre.

A escritura de Moacyr Scliar tematiza a tensão entre o "discurso da modernidade", que promove a dissoluçâo do passado pela aceleração do tempo provocando a fragmentação das experiências no espaço urbano, e a "memória coletiva" em perpétuo processo de reinvenção e atualização no sentido da busca da construção das identidades. Os pequenos atos de rebeldia e heroísmo frente à repetição incessante do mesmo na vida quotidiana, dos pequenos dramas, das tragédias individuais. A sua escritura é a busca de construir um sentido, reorganizar as experiências, reler o passado, trabalhar uma memória na busca de uma identidade, onde a Literatura serve de espelho. Mas, este espelho deduplica e refrata as múltiplas faces deste presente. O escritor-autor desloca-se então pelos labirintos da memória em busca de uma fórmula que o permita decifrar a Ordem, encontrar o Logos que explique seu ser-identidade. Embora essa tarefa nunca se complete de todo, pois o escritor para isso deveria se postar no lugar do "Aleph" onde todos as coisas são visíveis de todos os ângulos sem se misturarem (Borges, 1994). No entanto isso não é possível, nem desejável, pois esse seria o lugar dos profetas, a visão divina sobre as coisas e os seres, que superaria a divisão dos tempos e decretaria o "fim da história”. O lugar do escritor é a provisoriedade, que é a provisoriedade da vida, da historicidade de seu olhar sobre a realidade e da finitude de sua existência. Nossa condenação aos "cem anos de solidão" impõe às geraçôes futuras a tarefa de recomeçar, de reencenar os teatros da memória através da re-escritura da história pelas intimaçōes da contemporaneidade. 
Problematizar esse movimento de re-leitura da memória coletiva, através da poética dos tempos e espaços que constitui identidades na escritura ficcional de Scliar, é repensar as formas de conhecer o passado da sociedade porto-alegrense. Deve-se repensar as formas como o historiador da cultura tece na sua narrativa histórica - apelando à memória coletiva, à imaginação poética, a toda uma biblioteca de referências - as identidades e o próprio sujeito da enunciação, permitindo ou não a presença das falas dos outros, da alteridade. Ou seja, corresponderá ou não a atual forma de construir e narrar a História (metodologia, teoria, estilo) às demandas atuais da sociedade brasileira de memória e de constituição de uma sociedade verdadeiramente democrática, plural, participante da construção dos seus destinos, cidadã?

\section{REFERÊNCIAS BIBLIOGRÁFICAS}

BANN, Stephen. As invençōes da história. Ensaios sobre a representaçāo do passado. São Paulo: UNESP, 1994.

BARTHES, Roland. O rumor da língua. São Paulo: Brasiliense, 1988.

. Michelet. São Paulo: Cia. das Letras, 1988.

BORGES, Jorge Luis. Narraciones. Madrid: Cátedra, 1994.

DELEUZE, Gilles. L'image temps. Paris: Minuit, 1985.

- Proust e os signos. Rio de Janeiro: Forense Universitária, 1987.

- A dobra. Leibniz e o barroco. Campinas: Papirus, 1991.

FRYE, Northrop. O caminho crítico. Um ensaio sobre o contexto social da crítica literária. São Paulo: Perspectiva, 1973.

GADAMER, Hans-Georg. Verdad y metodo. 4. ed. Salamanca: Sigueme, 1991.

HEIDEGGER, Martin. Língua de tradição e língua técnica. Lisboa: Passagens, 1962.

LAPLATINE, François, TRINDADE, Liana. O que é imaginário? São Paulo: Brasiliense, 1997. (Col. Primeiros Passos, 309).

LEITE, Ligia C. M. O foco narrativo (ou a polêmica em torno da ilusão). 8. ed. São Paulo: Ática, 1997. (Série Princípios, 4).

LOWENTHAL, David. The past is a foreign country. New York: Cambridge University Press, 1985.

MAROBIN, Luiz. A Literatura no Rio Grande do Sul. Aspectos temáticos e estéticos. Porto Alegre: Martins Livreiro, 1985.

MERLEAU-PONTHY, Maurice. Fenomenologia da Percepção. São Paulo: Martins Fontes, 1996.

MONTEIRO, Charles. Porto Alegre. Urbanização e modernidade. Porto Alegre: EDIPUCRS, 1995. 
PÖTTER, Elisabeth Weber. A linguagem criadora e autônoma ou a organização dos aspectos peculiares da narrativa como instauradora dos conteúdos fantásticos na ficção de Moacyr Scliar. Porto Alegre: PUCRS, 1984. (Dissertação de Mestrado em Teoria Literária).

PRAZ, Mário. El pacto con la serpiente. México: Fondo de Cultura Economica, 1988.

RANCIÈRE, Jacques. Os nomes da História. São Paulo: EDUC; Pontes, 1994.

RICOEUR, Paul. Tempo e narrativa. Campinas: Papyrus, 1994. (T. 1, 2, 3).

RIEDEL, Dirce C. (org.). Narrativa. Ficçâo e História. Rio de Janeiro: Imago, 1988.

SARLO, Beatriz. Una modernidade periferica: Buenos Aires 1920 y 1930. Buenos Aires: Ediciones Nueva Visión, 1988.

SCLIAR, Moacyr. A Guerra do Bom Fim. $4^{a}$ ed.Porto Alegre: LP\&M, 1982. 90p. (Col. NOVALEITURA, 5) [1. ed. Porto Alegre: LP\&M, 1972].

. Os deuses de raquel. 4. ed. Porto Alegre: LP\&M, 1995. 82p. [1. ed. Porto Alegre: LP\&M, 1978].

- Os voluntários. Porto Alegre: LP\&M, 1979. 203 p.

SELISTRE, Maria Tereza. História e Fiç̧ão. A estranha nação de Rafael Mendes e a Jangada de Pedra. Porto Alegre: PUCRS, 1991. (Dissertação Mestrado em Teoria Literária).

SIMONE, Nathanael. "Um contista Ubíquo". In: SCLIAR, Moacyr. A balada do falso Messias. São Paulo: Ática, 1976.

STEEN, Edla van. Viver e escrever. Porto Alegre: LP\&M, 1981. (v. 1).

TODOROV, Tzvetan. As estruturas narrativas. $2^{a}$ ed. Sāo Paulo: Perspectiva, 1970.

ZILBERMAN, Regina. A Literatura no Rio Grande do Sul. Porto Alegre: LP\&M, 1980.

"1. (No começo), 2. (Um dia)". In: SCLIAR, Moacyr. Os melhores contos de Moacyr Scliar. 2. ed. São Paulo: Global, 1986.

WHITE, Hyden. A meta-história. São Paulo: EDUSP, 1992. 1994. 